\title{
Modeling exceptional high concentrations of carbonaceous aerosols observed at Pic du Midi in spring-summer 2003: Comparison with Sonnblick and Puy de Dôme
}

\author{
B. Guillaume ${ }^{\mathrm{a}, *}$, C. Liousse ${ }^{\mathrm{a}}$, C. Galy-Lacaux ${ }^{\mathrm{a}}$, R. Rosset ${ }^{\mathrm{a}}$, E. Gardrat ${ }^{\mathrm{a}}$, \\ H. Cachier ${ }^{\mathrm{b}}$, B. Bessagnet ${ }^{\mathrm{c}}$, N. Poisson ${ }^{\mathrm{d}}$ \\ ${ }^{a}$ Laboratoire d'Aérologie, 14 Avenue E. Belin, 31400 Toulouse, France \\ ${ }^{\mathrm{b}}$ Laboratoire des Sciences du Climat et de l'Environnement, Gif-sur-Yvette, France \\ ${ }^{\mathrm{c}}$ INERIS, Verneuil-en-Halatte, France \\ ${ }^{\mathrm{d}}$ ADEME, rue Louis Vicat, Paris, France
}

\begin{abstract}
Carbonaceous aerosols have been sampled weekly in 2002 and 2003 at Pic du Midi (PdMO), an isolated high-altitude Pyrenean station. High concentrations of both black carbon (BC) and total organic carbon (OC) have been observed during the exceptional prolonged warm dry spell over western Europe in spring-summer 2003, culminating during the first 2 weeks in August. The aerosol ORISAM-TM4 global model [Guillaume, B., Liousse, C., Rosset, R., Cachier, H., Van Velthoven, P., Bessagnet, B., Poisson, N., 2007. ORISAM-TM4: a new global sectional multi-component aerosol model including SOA formation - focus on carbonaceous BC and OC aerosols. Tellus B 59, 283-302.], together with new updated European emission inventories, appears apt to closely simulate at this PdMO site the BC and OC aerosol components during the whole 2002-2003 period, including the August 2003 heat wave. Further, ORISAM-TM4 provides unique detailed information on both primary and secondary OC fractions together with differentiated aerosol secondary anthropogenic (SOAA) vs. biogenic OC (SOAB) contributions, not accessible to measurements. Such comparisons have been extended to two other high-altitude European sites of the CARBOSOL programme, Sonnblick (Austrian Alps) and Puy de Dôme (central France). At these two sites, the agreement between simulations and measured values is clearly not so close as at PdMO, with systematic more elevated measured values of both $\mathrm{BC}$ and $\mathrm{OC}$, presumably due to local and regional sources.
\end{abstract}

Keywords: Heat wave 2003; Carbonaceous aerosols; European altitude sites; Model/measurement comparisons

\footnotetext{
*Corresponding author. Tel.: + 33561332743 ; fax: +33561332790 .

E-mail address: guib@aero.obs-mip.fr (B. Guillaume).
}

\section{Introduction}

An exceptional long-lasting warm dry spell has struck western Europe from March to mid-August 2003, associated with a persistent upper-ridge and surface high pressures. Extreme persistence of this 
ridge was related to a prolonged positive phase of the East Atlantic teleconnection pattern (Bell and Eichler, 2005). Under such highly stable persistent anticyclonic conditions, France experienced a 20 days period in June-August 2003 with daily maximum temperatures exceeding $34{ }^{\circ} \mathrm{C}$, well above climatological means. Two particular periods of exceptional heat occurred in summer 2003, in June and during the first-half of August. This latter was the most severe, adding high temperature positive variability (Schar et al., 2004) to the summer annual temperature peaks. In France, 15,000 heat-related deaths were reported between late July and midAugust 2003 (Le Tertre et al., 2006). The exceptional year 2003 is considered as a manifestation of present climate change and a possible future for European summers (Beniston, 2004). To further highlight this issue, dedicated long-term measurements at background sites are highly needed: the high-altitude Pic du Midi observatory (PdMO) offers such a unique opportunity.

Built in 1874 , PdMO $\left(43^{\circ} 04^{\prime} \mathrm{N}, 0^{\circ} 09^{\prime} \mathrm{E}, 2862 \mathrm{~m}\right.$ a.s.l.) is a long-term established station for meteorological and ozone measurements. Close to the Neouvielle national park, on top of an isolated peak in central Pyrenees, PdMO is representative of free tropospheric air at temperate latitudes, far from urban areas and local/regional direct pollution effects. It is a representative sentinel site for sampling long-range pollution transport over western Europe. Climatological studies at PdMO covering the whole 20th century (Bucher and Dessens, 1991; Dessens and Bucher, 1995) have shown mean temperature increases of $0.94{ }^{\circ} \mathrm{C} / 100$ years. Concomittant $15 \%$ increases in relative humidities and cloud cover have been observed. Also, with ozone time series beginning in 1874, significant average ozone concentration increases have been measured, from about $10 \mathrm{ppb}$ to present $50 \mathrm{ppb}$, confirmed at other European high-altitude stations such as Zugpitze, Hohenpeissenberg and Jungfraujoch (Marenco et al., 1994). Other observations close to PdMO, also indicative of possible climate change have been made, such as the dramatic decrease of Pyrenean glaciers $\left(35 \mathrm{~km}^{2}\right.$ in 1900 against present $5 \mathrm{~km}^{2}$; René, 2004) or increased trunk radial growth of mountain pines (Pinus uncinata) for at least the last 20 years (Rolland and Florence-Schueller, 1998).

Recently, PdMO has been further instrumented for organic acids, carbonaceous and inorganic aerosol components. Using these and other European high-altitude data in the CARBOSOL (Present and retrospective state of organic versus inorganic aerosol over Europe) (Legrand and Puxbaum, 2007) programme for the years 2002 and 2003, Legrand et al. (2005) have reported high $\mathrm{C}_{2}-\mathrm{C}_{5}$ dicarboxylic acid concentrations in spring-summer 2003. Such high values during this period are assumed to be due to the prevailing climatic conditions, with warmer temperatures and lower precipitation enhancing both the atmospheric oxidant levels and biogenic emissions of aerosol precursors and consequently, increasing secondary organic aerosol (SOA) formation. Our focus here is on carbonaceous aerosol data, both black carbon (BC) and total organic carbon (OC). These new 2-year measurements have been compared to primary OC (OCp) and secondary OC (SOA fraction) from ORISAM-TM4 (Guillaume et al., 2007) global simulations, with meteorological updating every $6 \mathrm{~h}$. Information is next given on ORISAM-TM4 and the experiments (part 2), then on results and comparisons with measurements (part 3), including extensions to two other high-altitude sites, Sonnblick (SBO) and Puy de Dôme (PDD).

\section{Experimental procedures, modeling and emission description}

Weekly collected filters at PdMO have been analyzed for $\mathrm{BC}$ and $\mathrm{OC}$ aerosol components since March 2002. The sampling line for carbonaceous aerosols comprises a pump $\left(\mathrm{KNF}^{\circledR}, 1 \mathrm{~m}^{3} \mathrm{~h}^{-1}\right)$, a gas meter and an on-line $47 \mathrm{~mm}$ diameter filter holder (NILU Products $\mathrm{AS}^{\mathbb{R}}$ ). Aerosols are collected on quartz filters QMA $^{\circledR}$ Whatman preheated during $24 \mathrm{~h}$ at $450^{\circ} \mathrm{C}$, so as to lower blank levels. Several procedures are possible (Chow et al., 2001) for BC and $\mathrm{OC}$ measurements, with major uncertainties due to BC vs. OC split. Using a DRI analyzer, we have decided to apply the IMPROVE thermal/ optical (TOR) protocol (Chow et al., 2004). Under carbonate free assumption, this procedure, improved through optical charring correction (Johnson et al., 1981), results in a $20 \%$ level of uncertainties in $\mathrm{BC}$ vs. OC split.

The global CTM (Chemistry Transport Model) ORISAM-TM4 is able to simulate BC and OC, their emissions by anthropogenic sources, their transport, their "ageing" in the atmosphere through SOA formation generating new particles and condensation onto existing ones, coagulation between particles and finally, their deposition to the Earth's 
surface. This model is fully documented in Guillaume et al. (2007). Only relevant information for our present purpose is recalled here.

Special emphasis has been put in this model on emission inventories, key issues for BC, OCp and SOA modeling. Emissions of carbonaceous aerosols comprise two steps. First, spatially variable mass emission fluxes (e.g., in tons/month/grid cell) are issued from $\mathrm{BC}$ and $\mathrm{OCp}$ emission inventories, respectively, for fossil fuels, biofuels and biomass burning sources. European fossil fuel (FF) and biofuel (BF) combustion emission inventories for $\mathrm{BC}$ and $\mathrm{OCp}$ (including traffic, industries, domestic use), for the year 2000 (Guillaume and Liousse, 2004) have been merged within global ones issued from Junker and Liousse (2007).

Special attention has also been paid to biomass burning $\mathrm{BC}$ and $\mathrm{OC}$ emission sources, possibly impinging on PdMO in summer. The emission inventory for 2002 and 2003 includes the severe forest fires which occurred in July and August 2003, mostly in Portugal and Spain. In fact, the net effect of these fires on modeled $\mathrm{BC}$ and $\mathrm{OC}$ concentrations (not displayed in Figs. 2 and 3 ) is $<2 \%$. This low contribution can be traced back to the specific stable anticyclonic situation in July-August 2003 over western Europe. In this situation, systematic back trajectories ending at PdMO (not shown here) have been computed using both HYSPLIT (http:// www.arl.noaa.gov) and TM4 simulations for the 15-day period preceding and covering the 2003 heat wave peak (4-12 August 2003). More than 95\% of these backward trajectories have not passed over the Iberian fires. As for few ones having passed over these fires, they bypass western Europe during this period, off the Atlantic coast, then anticyclonically turning over Ireland, England, the Netherlands (Hodzic et al., 2006), Germany, Central Europe and Italy.

Second, to get size-distributed emissions, the above fluxes are multiplied by a spatially uniform normalized size-distribution consisting in two lognormal modes: a fine mode $(m=0.23 \mu \mathrm{m}, \sigma=1.89)$ accounting for $100 \%$ of BC and $90 \%$ of OCp, and a coarse one $(m=2.5 \mu \mathrm{m}, \sigma=1.89)$ for the other $10 \%$ OCp ( $m$, median diameter and $\sigma$, dispersion coefficient). This latter distribution is typical of mixed urban, industrial, rural areas such as the Marseilles region (Escompte programme; Cousin et al., 2005). Once emitted, these particles evolve in sizes as they are processed through microphysical processes and chemical transformations (e.g., con- densation, absorption, coagulation), with subsequent formation of sulfates, nitrates, ammonia and SOA.

To simulate SOA formation, one major asset of ORISAM-TM4 lies in the development of a comprehensive gas phase scheme interacting with a detailed multi-species aerosol phase (organics in interaction with dust, sea-salt and inorganics). This gas scheme combines a typical $\mathrm{O}_{3}$-dedicated scheme (CBM-4 modified after Houweling et al., 1998) with a more specifically SOA-dedicated one (Guillaume et al., 2007), this latter including for instance VOC single-oxidation reactions with the $\mathrm{OH}$ radical. Further, in the sectional aerosol module ORISAM (Bessagnet et al., 2002; Liousse et al., 2005; Cousin et al., 2005), thermodynamical equilibrium partitioning between the gas and aerosol phases are separately computed (Guillaume et al., 2007) in each section (currently eight sections) for SOA in connection with secondary inorganics (sulfates, nitrates, ammonium). SOA have differentiated origins in the model, whether anthropogenic (SOAA) and/or biogenic (SOAB). For biogenics, the terpene precursors are lumped into a single class, with emissions issued from the POET inventory (Olivier et al., 2003). Isoprene is only included in the $\mathrm{O}_{3}$-dedicated gas scheme, but not as recently proposed as a SOA precursor (Lim et al., 2005). Two classes (toluene and xylenes) in anthropogenic organic precursors are used, both in the $\mathrm{O}_{3}$ and SOA-dedicated schemes. Benzene is not yet introduced in SOA formation. These anthropogenic VOC species are also issued from the POET inventory.

Further, this modeling framework will be apt to readily accommodate potential SOA precursors after additional development both in the gas and aerosol phases (e.g., benzene and isoprene as SOA precursors, oligomers in organic particles: cf. Pun and Seigneur, 2007). One main ORISAM-TM4 deficiency is in its coarse spatial resolution, reflected in poor treatment of local orographic effects or emission point sources.

\section{Results}

Fig. 1 displays a photomontage of the sequence of weekly filters collected at PdMO from August 2002 to December 2003. Blackness of these filters is a significant qualitative indication of the evolution of carbonaceous aerosol air contents at PdMO. Two major results appear in this figure. First, and most 


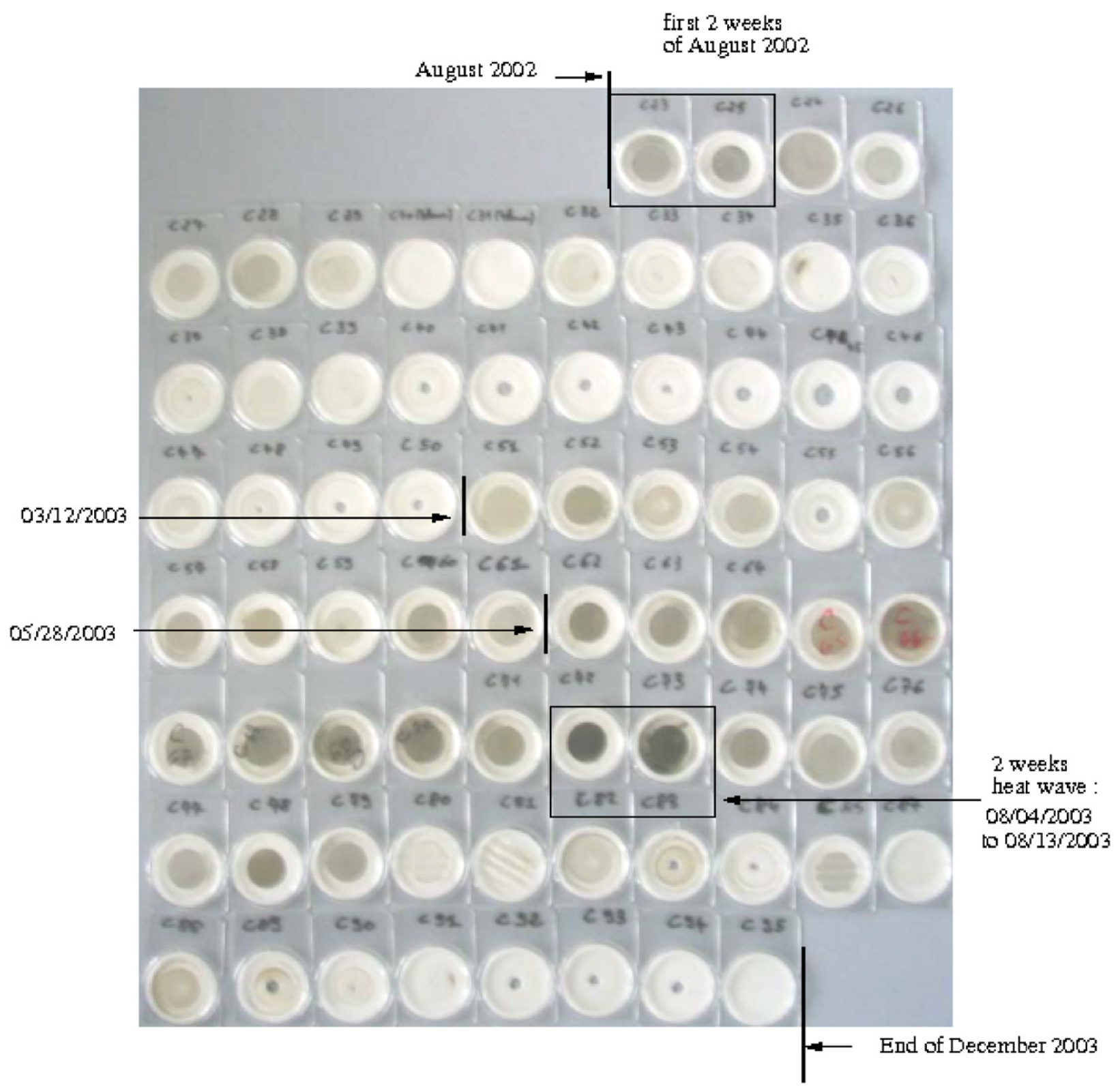

Fig. 1. Weekly collected carbonaceous aerosol filters at PdMO for the period August 2002-December 2003 (boxed filters for the two first August weeks, respectively, in 2002 and 2003).

prominently, the boxed filters in August 2003 are by far the blackest of the whole set, thus denoting highest carbonaceous pollution. Second, filter blackening in 2003 appears early in mid-March and lasts until mid-August, coinciding with the European warm dry spell which began in March. These spring-summer high $\mathrm{BC}$ and $\mathrm{OC}$ pollution levels at PdMO clearly exceed those in springsummer 2002, with spring 2003 values even higher than in summer 2002. Experimental results at PdMO (open diamonds) are reported for $\mathrm{BC}$ and OC concentrations, respectively, in Figs. 2 and $3 \mathrm{a}$. These results are also compared to $\mathrm{BC}$ and $\mathrm{OC}$ ORISAM-TM4 simulations during the period from April 2002 to August 2003.

First, measured and modeled concentrations of the combustion tracer BC at PdMO for this period are compared in Fig. 2a. Most prominently, these 
a

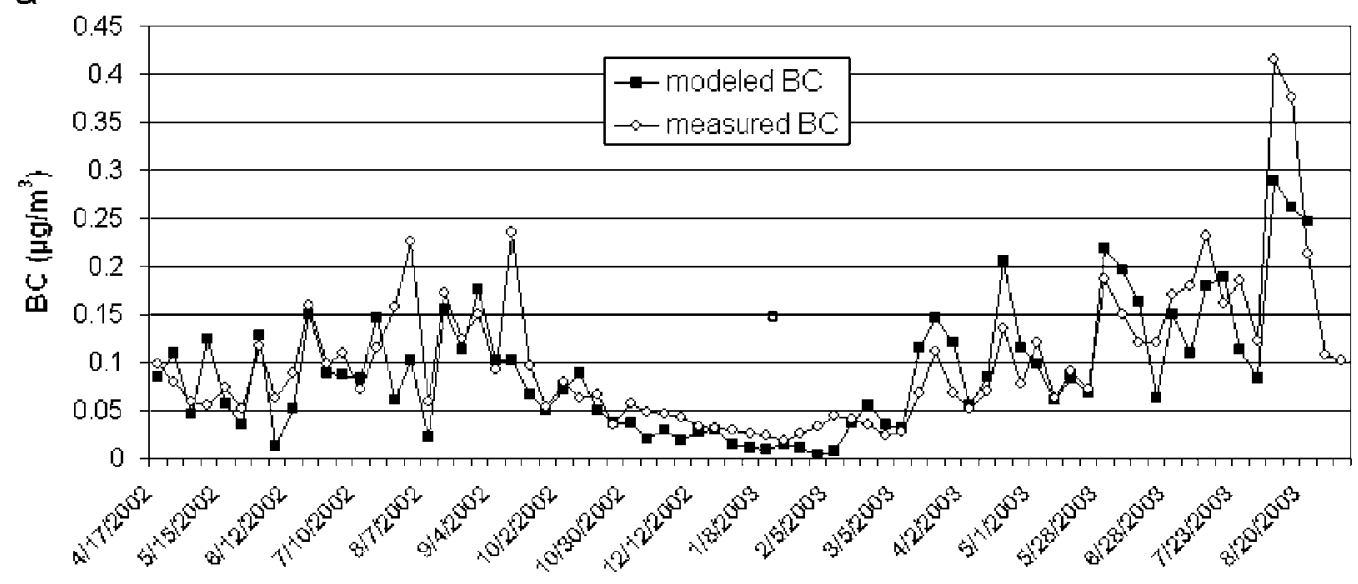

b

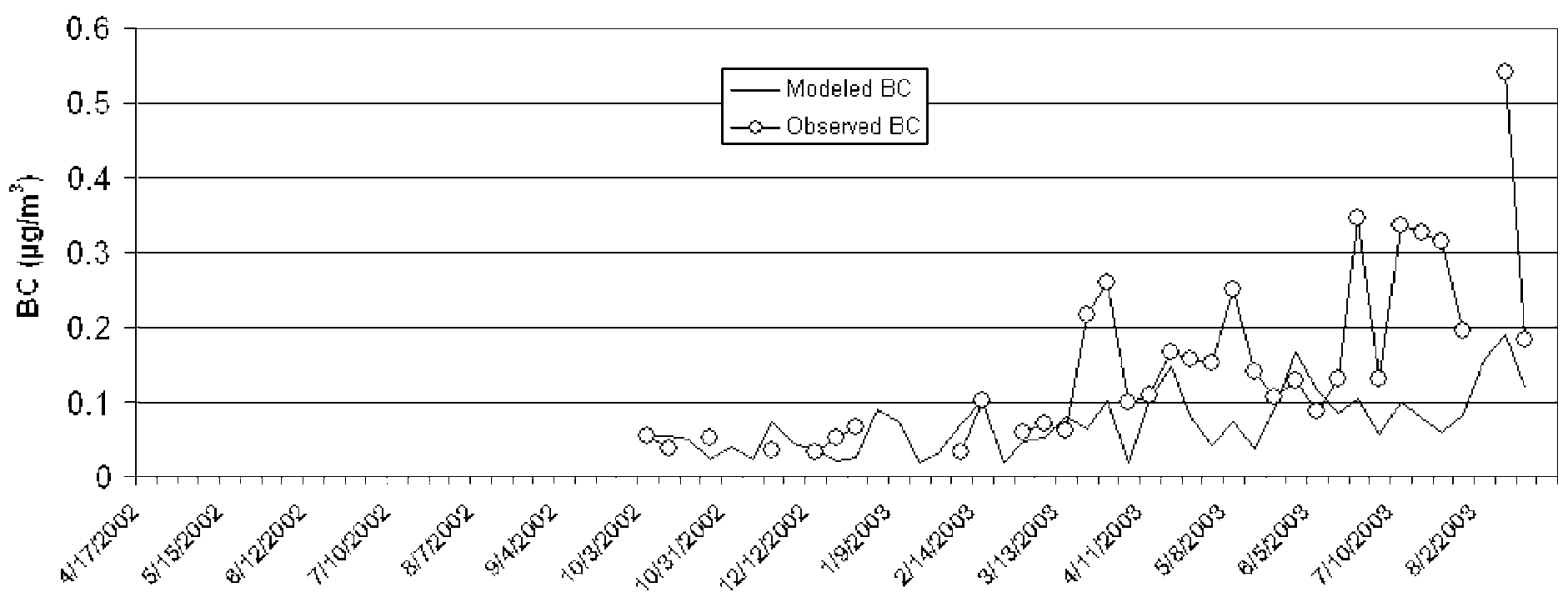

C

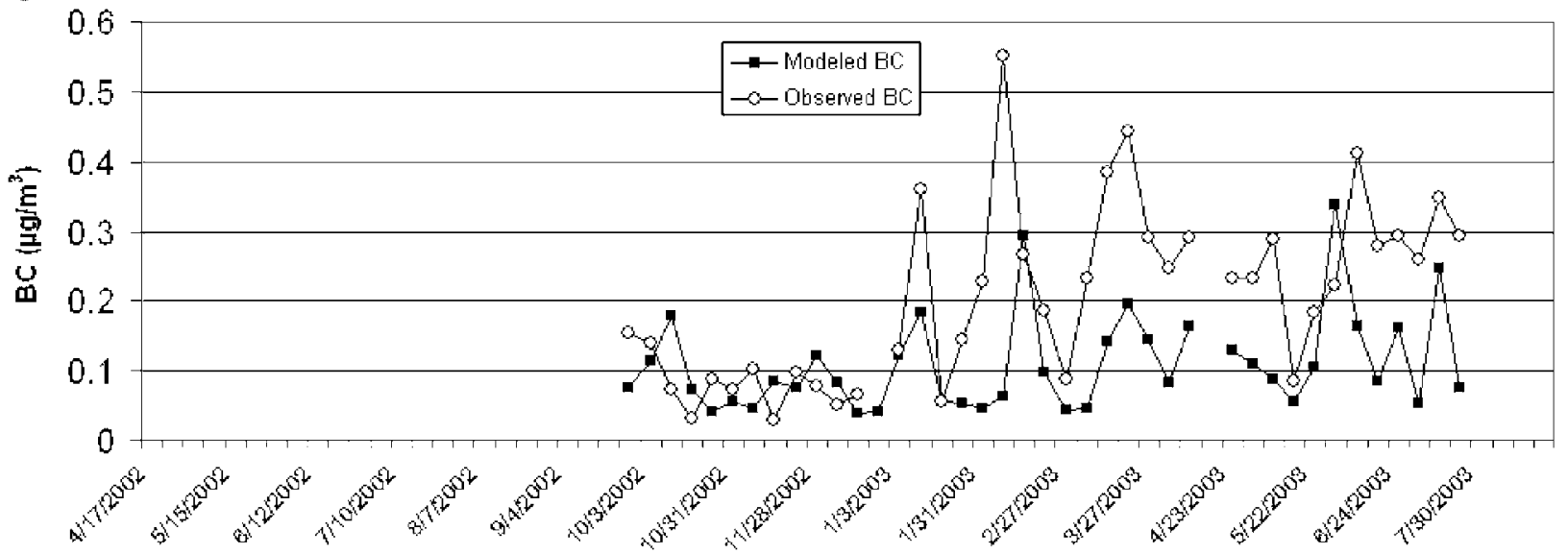

Fig. 2. Measured vs. modeled BC concentrations (in $\mu \mathrm{g} \mathrm{m}^{-3}$ ) from April 2002 to September 2003 (open diamonds for measurements, black

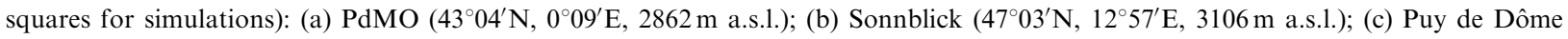
$\left(45^{\circ} 46^{\prime} \mathrm{N}, 2^{\circ} 57^{\prime} \mathrm{E}, 1450 \mathrm{~m}\right.$ a.s.l.). Puy de Dôme and Sonnblick data are from Pio et al. (2007).

two curves are in rather close agreement as regards their trends, magnitudes and even peak timings, with only $19 \%$ average differences. Individually, the highest recorded $\mathrm{BC}$ peak in August 2003 is underestimated by $35 \%$ in the simulation. As for the other concentration peaks, either measured 
a

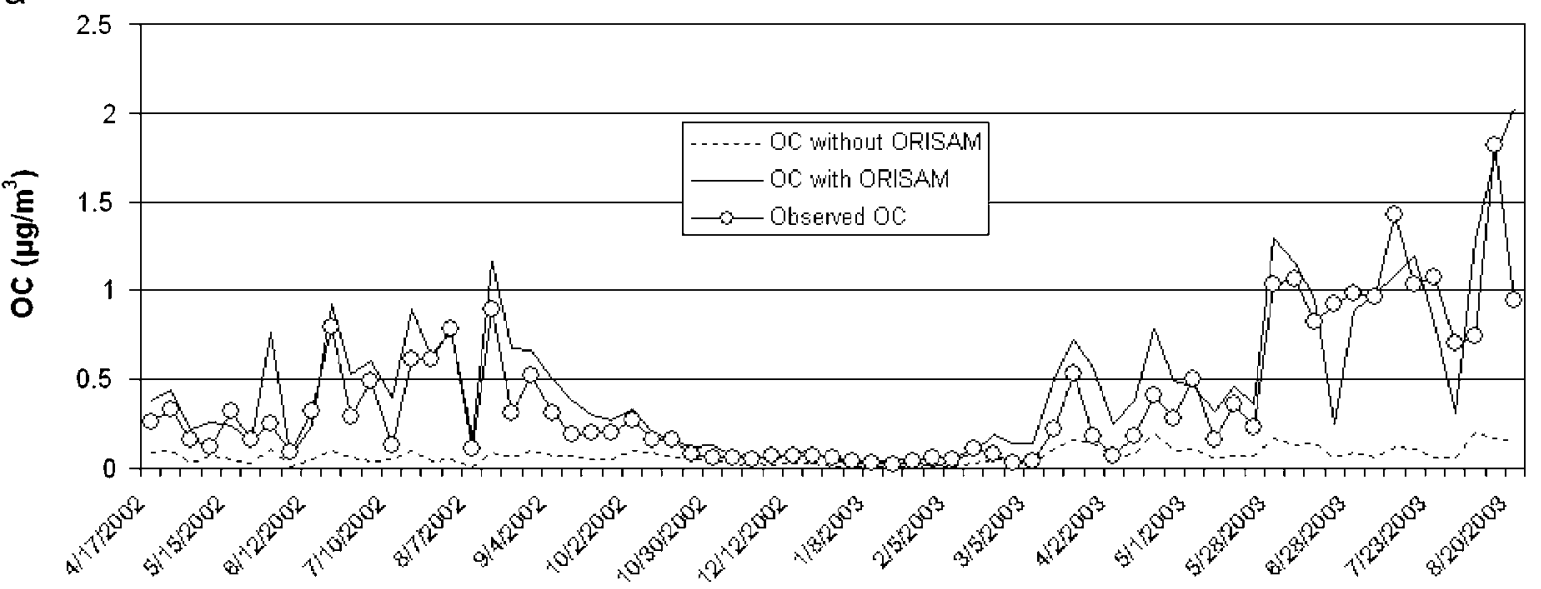

b

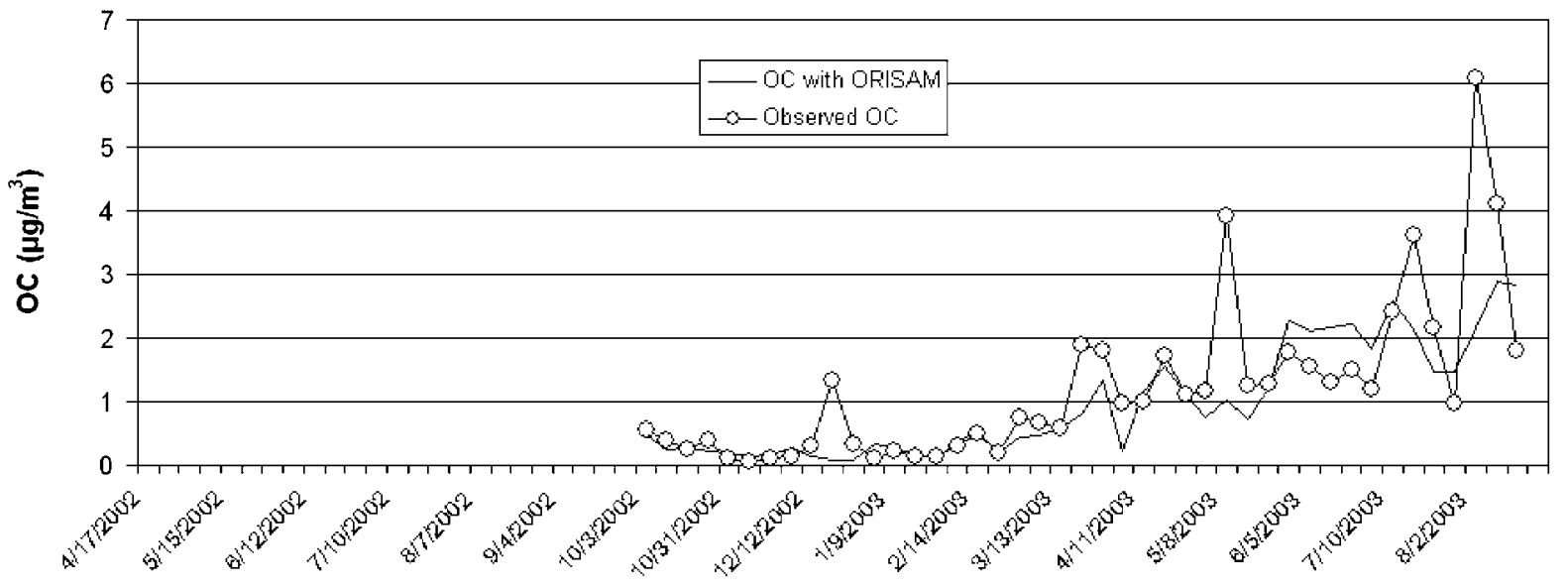

C

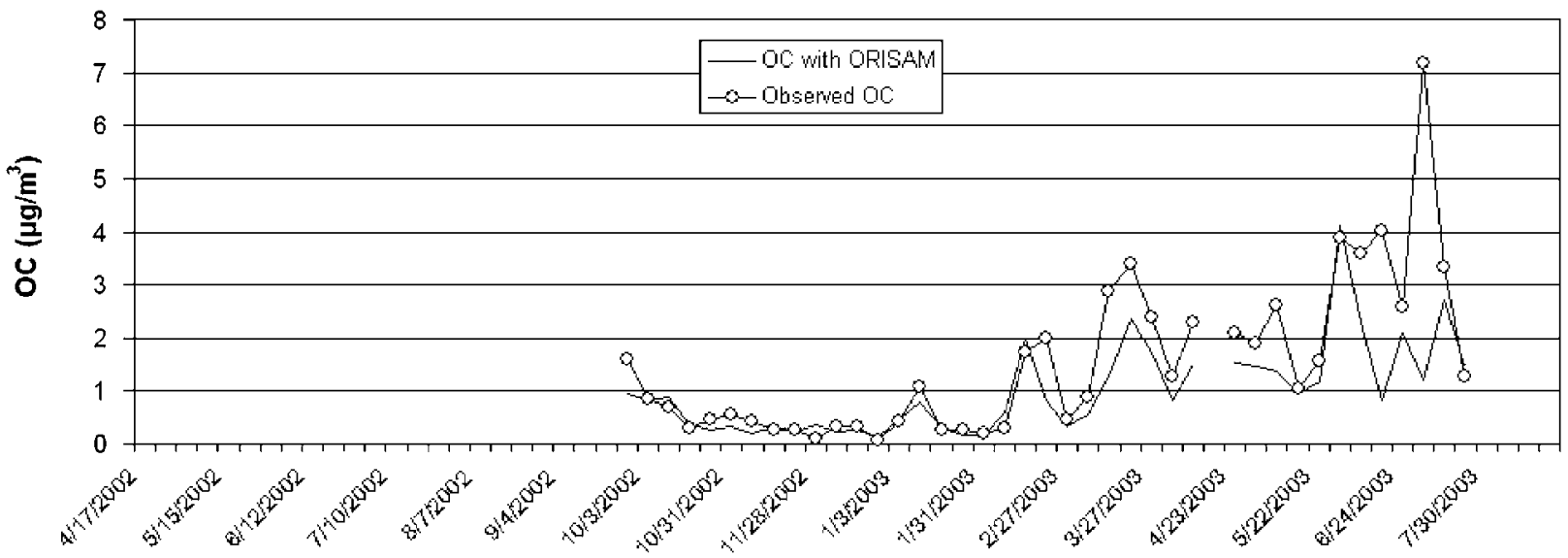

Fig. 3. Measured (open diamonds) vs. modeled OC concentrations (in $\mu \mathrm{g} \mathrm{m}^{-3}$ ), for the same period as in Fig. 2 (solid line for modeled OC with the full ORISAM model, dotted line for OC using the ORISAM tracer version), at: (a) PdMO, (b) Sonnblick and (c) Puy-de-Dôme.

or modeled, they consistently parallel filter blacknesses in Fig. 1, including the cleanest filters in winter 2002-2003. Considering the emission inven- tories discussed above and coarse ORISAM-TM4 resolution, one preliminary conclusion at this stage, is that large-scale pollution transport has a 
predominant impact on $\mathrm{BC}$ levels at the highaltitude PdMO site.

Now considering measured $\mathrm{OC}$ at $\mathrm{PdMO}$ in Fig. 3a, its overall evolution is rather similar to $\mathrm{BC}$ in Fig. 2a, though with average fivefold increased levels. First, model tests were made without the aerosol model ORISAM, just using OCp emission values multiplied by an empirical 1.25 constant factor aimed at roughly accounting for SOA formation (Solmon et al., 2006). Clearly in Fig. 3a, the corresponding dotted line completely fails to capture observed OC, most particularly in springs and summers 2002 and 2003.

In order to reduce the discrepancies between these modeled and measured OC concentrations at PdMO, the full ORISAM-TM4 model (Guillaume et al., 2007) has been run in a second series of tests, keeping the same emission inventories, but now including detailed temperature- and photochemistry-dependent SOA formation, with several VOC gas phase oxidation stages and gas-particle partition yields, in the presence of $\mathrm{NO}_{x}, \mathrm{O}_{3}, \mathrm{NO}_{3}$ and $\mathrm{OH}$ radicals. Striking improvements are observed in Fig. $3 \mathrm{a}$, whether in the magnitudes or timing of the peaks, both in 2002 and 2003. This result emphasizes the prominent role of SOA formation in spring and summer, during air mass transit over the European emission sources, particularly within such a photochemically active atmosphere as during the 2003 hot dry spell (Legrand et al., 2005). Though local scale pollution effects combining local sources with local thermal circulations are not to be fully discarded, good performance of the ORISAM-TM4 model in retrieving the major part of measured $\mathrm{BC}$ and $\mathrm{OC}$ concentrations emphasizes large scale continental transport as giving a main contribution to the pollution of high-altitude European sites such as PdMO.

Two other set of measurements at west and central European high-altitude sites, during the CARBOSOL programme, are also used from October 2002 to August 2003 for extended comparisons with PdMO and ORISAM-TM4 simulations. Figs. 2 and 3 display the comparisons between modeled and observed $\mathrm{BC}$ and $\mathrm{OC}$ concentrations at SBO (Figs. 2b and $3 b$ ) and PDD (Figs. 2c and $3 c)$. Furthermore, SOAA and SOAB are also simulated, though not experimentally discriminated, and compared at these three stations (Fig. 4). These sites, respectively Pic du Midi (PdMO; in the French Pyrenees), Puy de Dôme (PDD; in central France) and Sonnblick (SBO; in the Austrian Alps), classified as background stations in the European high-altitude pollution network, differ in several respects. PdMO and SBO are both about $3000 \mathrm{~m}$ a.s.1., whereas PDD is much lower $(1460 \mathrm{~m})$. They are in various local and regional surroundings, differently interacting with the long-range transport. In this regards, due to its altitude and isolation within the Pyrenean barrier far from strong local pollution sources and its western-most European location, we have seen that PdMO can a priori be assumed as a clean reference station mostly reflecting large-scale pollution transport. This is not as clearly the case at SBO and more specifically at PDD (respectively, Figs. $2 b$ and c), which display first higher background $\mathrm{BC}$ pollution levels than PdMO (Fig. 2a) and second, systematic model underestimation of $\mathrm{BC}$ concentrations, the difference presumably being attributable to additional local/regional BC sources. This is also reflected in OC values at SBO and PDD (peak values from 4 to $7 \mu \mathrm{g} \mathrm{m}^{-3}$ in summer 2003), higher than at PdMO (always below $2 \mu \mathrm{g} \mathrm{m}^{-3}$ ) during the whole period. This is also consistent with simulated SOAA and SOAB (Fig. 4) concentrations at the three stations. For SOAA, a mean value of $0.5 \mu \mathrm{g} \mathrm{m}^{-3}$ is observed in spring-summer 2003 at PDD and SBO, against only $0.25 \mu \mathrm{g} \mathrm{m}^{-3}$ at PdMO. Further, at PDD, the anthropogenic SOAA contribution is greater than the SOAB one. Except in Spring 2003, the reverse is clearly observed in summer 2003 at SBO. As for PdMO, both summers 2002 and 2003 consistently display significantly higher SOAB than SOAA contributions. All these results from Figs. 2-4 allow to qualify, at least for the period under study, PdMO as the cleanest of all three sites, i.e., the least affected by anthropogenic sources, less than SBO and more noticeably less than PDD. Such differences can presumably be attributed to different altitudes and/or local/regional surrounding effects.

\section{Conclusions}

$\mathrm{BC}$ as a combustion tracer, together with total OC (primary OCp plus secondary SOA fractions) are two sensitive complementary species, both required for unraveling the complex evolving characteristics of carbonaceous aerosols, from their emissions, during their transport, physico-chemical transformations, to their deposition. $\mathrm{BC}$ and $\mathrm{OC}$ were weekly sampled in 2002 and 2003 at PdMO, a long-term established high-altitude Pyrenean sentinel site. The year 2003 was characterized by a 


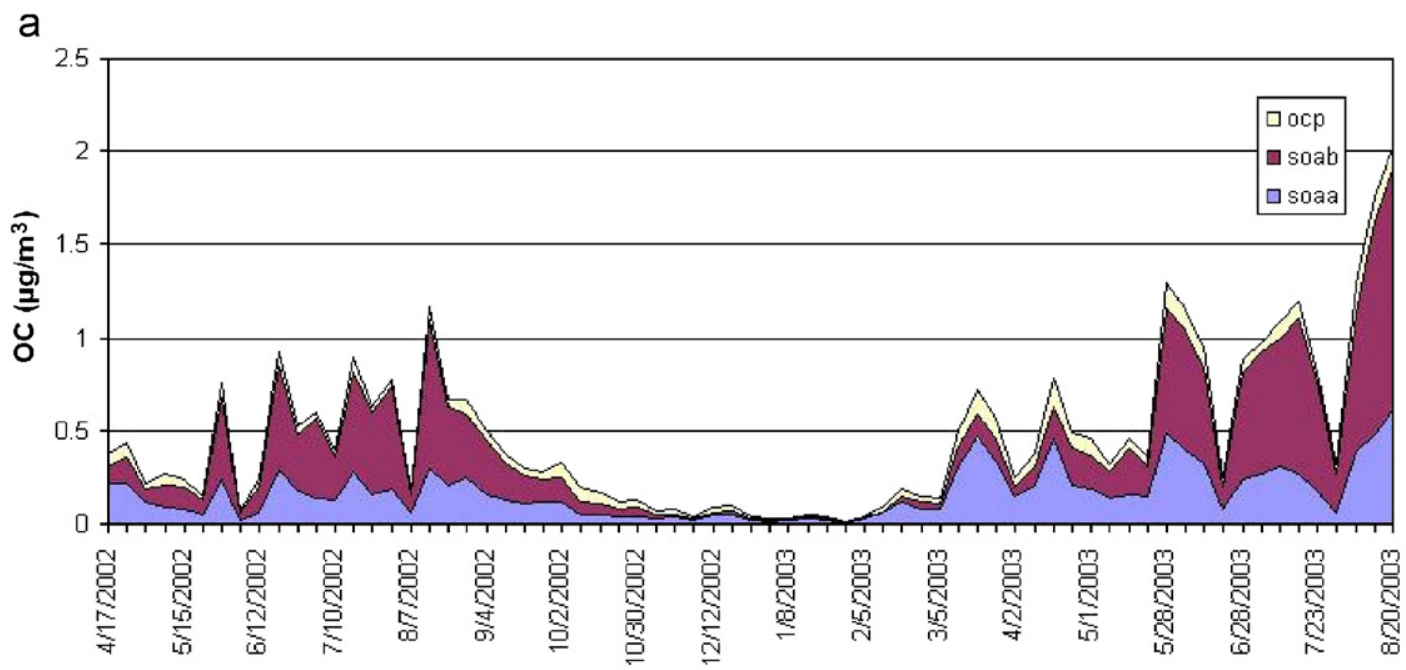

b

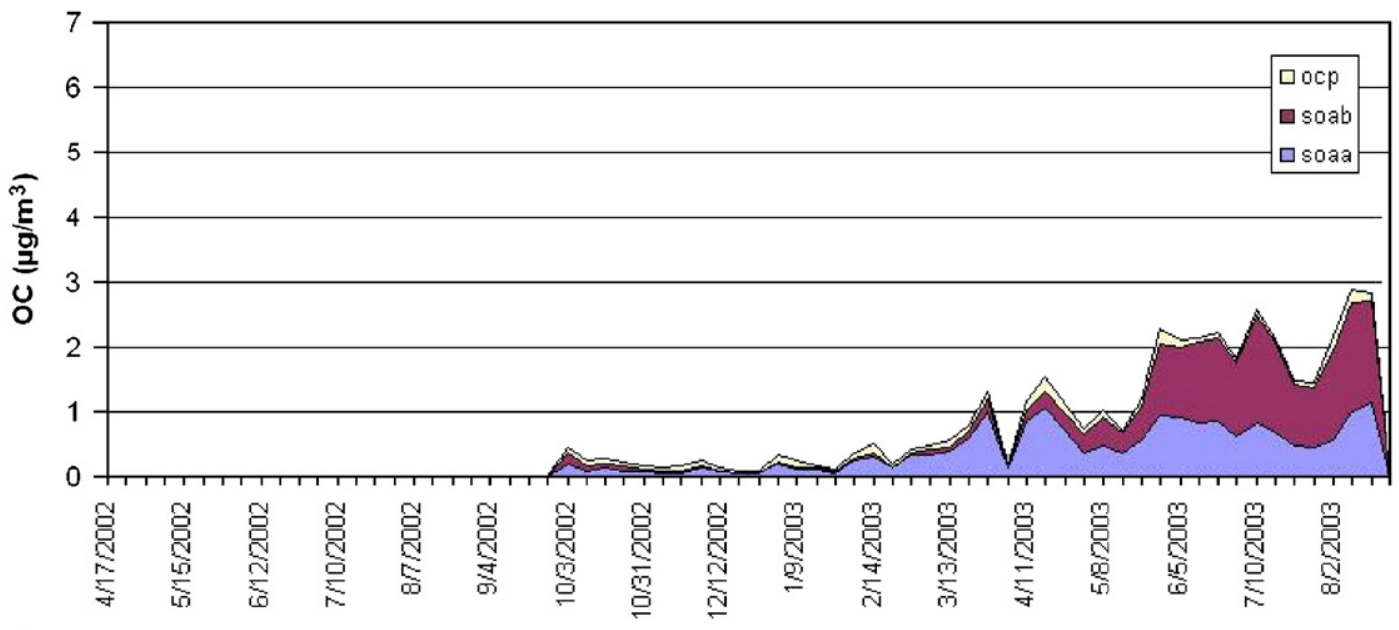

C

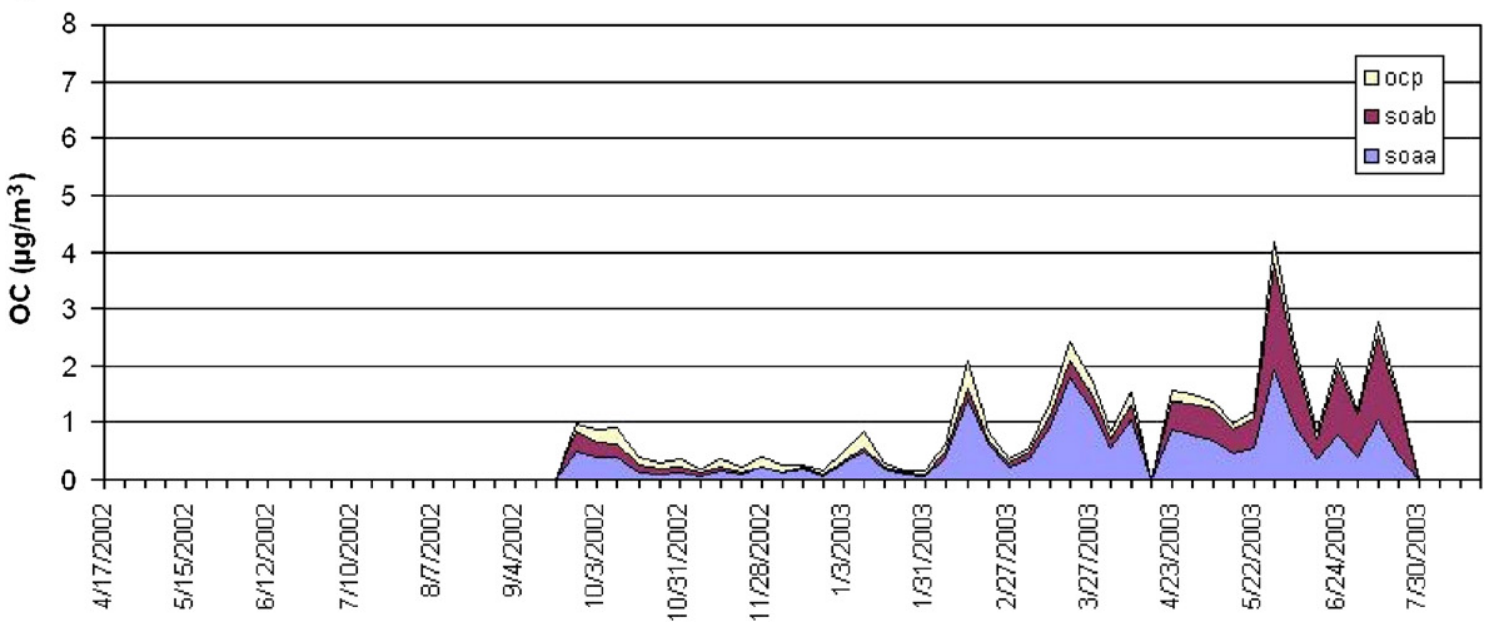

Fig. 4. Modeled relative concentrations of OCp, anthropogenic SOA (SOAA) and biogenic SOA (SOAB) at: (a) Pic du Midi, (b) Sonnblick and (c) Puy de Dôme, from April 2002 to August 2003. 
prolonged hot dry spell beginning in May and culminating in August. Significant differences in $\mathrm{BC}$ and $\mathrm{OC}$ concentrations were observed between 2002 and 2003, thus offering a valuable benchtest for the ORISAM-TM4 aerosol model (Guillaume et al., 2007). Carbonaceous aerosol emission inventories have been implemented in ORISAMTM4, with meteorological updating every $6 \mathrm{~h}$ during the whole $2002-2003$ period. Due to coarse $\left(3^{\circ} \times 2^{\circ}\right)$ horizontal resolution relevant to large-scale continental pollution, ORISAM-TM4 surprisingly revealed apt to rather closely simulate measured carbonaceous aerosol concentrations in 2002 and 2003 at PdMO. This result would imply that largescale pollution is most prominent at this site, as can in fact could be expected at such a representative background air quality observatory. Two other measurement dataset (CARBOSOL programme) at the high-altitude sites, Sonnblick (SBO) and Puy de Dôme (PDD), have also been compared to ORISAM-TM4 simulations, showing less satisfactory comparisons with systematic higher measured $\mathrm{BC}$ and $\mathrm{OC}$ values. Based on these comparisons and on respective modeled anthropogenic contributions at these three sites, PdMO appears as the cleanest one for the period under study. Major results of these model/measurement comparisons are to be emphasized here, particularly at PdMO. First, the ORISAM tracer-only version gave surprisingly high correlations between measured and modeled BC, both in 2002 and 2003. Second, the full ORISAM-TM4 model with explicit modeling of temperature-dependent SOA formation was required to closely simulate measured OC. This was specifically the case in spring-summer 2003 as compared to 2002, due to high oxidant levels resulting in increased SOA formation (Legrand et al., 2005). Third, as a bonus to OC measurements, ORISAM uniquely provided differentiated anthropogenic vs. biogenic aerosol relative OC contributions, not accessible to measurements, at these three elevated sites.

\section{Acknowledgments}

P. Castera, V. Pont and E. Terrenoire are highly acknowledged for sustained technical and instrumental support. We also thank A. Merlos and J.M. Abbadie for maintenance of the technical platform at Pic du Midi. Finally, we thank Casimiro Pio and Michel Legrand who provided the CARBOSOL data.

\section{References}

Bell, G., Eichler, T., 2005. Special climate summary-exceptional heat and dryness in Europe during April-August 2003. $\langle$ http://www.ncep.noaa.gov $\rangle$.

Beniston, M., 2004. The 2003 heat wave in Europe: a shape of things to come? An analysis based on Swiss climatological data and model simulations. Geophysical Research Letters 31, L02202.

Bessagnet, B., Hodzic, A., Vautard, R., Beekmann, M., Cheinet, S., Honoré, C., Liousse, C., Rouil, L., 2002. Aerosol modelling with CHIMERE - preliminary evaluation at the continental scale. Atmospheric Environment 38, 2803-2817.

Bucher, A., Dessens, J., 1991. Secular trend of surface temperature at an elevated observatory in the Pyrenees. Journal of Climate 4, 859-868.

Chow, J.C., Watson, J.G., Crow, D., Lowenthal, D.H., Merrifield, T.M., 2001. Comparison of IMPROVE and NIOSH carbon measurements. Aerosol Science and Technology 34 (1), 23-34.

Chow, J.C., Watson, J.G., Chen, L.W.A., Arnott, W.P., Moosmuller, H., Fung, K., 2004. Equivalence of elemental carbon by the thermal/optical reflectance and transmittance with different temperature protocols. Environmental Science and Technology 38 (16), 4414-4422.

Cousin, F., Liousse, C., Cachier, H., Bessagnet, B., Guillaume, B., Rosset, R., 2005. Aerosol modelling and validation during Escompte 2001. Atmospheric Environment 39 (8), 1539-1550.

Dessens, J., Bucher, A., 1995. Changes in minimum and maximum temperatures at the Pic du Midi in relation with humidity and cloudiness, 1882-1984. Atmospheric Research $37,147-162$.

Guillaume, B., Liousse, C., 2004. Development of carbonaceous aerosol emission inventories from fossil fuel over Europe at continental scale with focus on traffic at national and regional scales. ADEME (French Ministery of Environment and Sustainable Development) Report, Project 0262050.

Guillaume, B., Liousse, C., Rosset, R., Cachier, H., Van Velthoven, P., Bessagnet, B., Poisson, N., 2007. ORISAMTM4: a new global sectional multi-component aerosol model including SOA formation - focus on carbonaceous $\mathrm{BC}$ and OC aerosols. Tellus B 59, 283-302.

Hodzic, A., Vautard, R., Chepfer, H., Goloub, P., Chazette, P., Menut, L., 2006. Evolution of aerosol optical thickness over Europe during the August 2003 heat wave as seen from POLDER data and CHIMERE model simulations. Atmospheric Chemistry and Physics 6, 1853-1864.

Houweling, S., Dentener, F., Lelieveld, J., 1998. The impact of non-methane hydrocarbon compounds on tropospheric photochemistry. Journal of Geophysical Research 103, 10673-10696.

Johnson, R.L., Shah, J.J., Cary, R.A., Huntzicker, J.J., 1981. An automated thermal-optical method for the analysis of carbonaceous aerosol. In: Macias, E.S., Hopke, P.K. (Eds.), Atmospheric Aerosol: Source/Air Quality Relationships. American Chemical Society, Washington, DC, pp. 223-233.

Junker, C., Liousse, C., 2007. A global emission inventory of carbonaceous aerosol from historic records of fossil fuel and biofuel consumption for the period 1860-1997. ACPD 6, 4897-4927. 
Le Tertre, A., Lefranc, A., Eilstein, D., Declercq, C., Medina, S., Blanchard, M., Chardon, B., Fabre, P., Filleul, L., Jusot, J.-F., Pascal, L., Prouvost, H., Cassadou, S., Ledrans, M., 2006. Impact of the 2003 heatwave on all-cause mortality in 9 French cities. Epidemiology 17, 75-79.

Legrand, M., Preunkert, S., Galy-Lacaux, C., Liousse, C., Wagenbach, D., 2005. Atmospheric year-round records of dicarboxylic acids and sulfate at three French sites located between 630 and $4360 \mathrm{~m}$ elevation. Journal of Geophysical Research 110, D13302.

Legrand, M., Puxbaum, H., 2007. Summary of the CARBOSOL project: present and retrospective state of organic versus inorganic aerosol over Europe. Journal of Geophysical Research 112, doi:10.1029/2006JD008271.

Lim, H.J., Carlton, A.G., Turpin, B.J., 2005. Isoprene forms secondary organic aerosol through cloud processing: model simulations. Environmental Science and Technology 39, 4441-4446.

Liousse, C., Michel, C., Bessagnet, B., Cachier, H., Rosset, R., 2005. 0D-modelling of carbonaceous aerosols over Greater Paris focusing on the organic particle formation. Journal of Atmospheric Chemistry 51 (2), 207-221.

Marenco, A., Gouget, H., Nedelec, P., Pages, J.P., Karcher, F., 1994. Evidence of a long-term increase in tropospheric ozone from Pic du Midi data series: consequences-positive radiative forcing. Journal of Geophysical Research 99, $16617-16632$.
Olivier, J., Peters, J., Granier, C., Petron, G., Müller, J.-F., Wallens, S., 2003. Present and future surface emissions of atmospheric compounds. POET Report \#2, EU Project EVK2-1999-00011.

Pio, C.A., Legrand, M., Oliveira, T., Afonso, J., Santos, C., Caseiro, A., Fialho, P., Barata, F., Puxbaum, H., SanchezOchao, A., Kasper-Giebl, A., Gelencsér, A., Preunkert, S., Schock, M., 2007. Climatology of aerosol composition (organic versus inorganic) at non-urban sites on a west-east transect across Europe. Journal of Geophysical Research 112, D23S02, doi:10.1029/2006JD008038.

Pun, B.K., Seigneur, C., 2007. Investigative modeling of new pathways for secondary organic aerosol formation. Atmospheric Chemistry and Physics Discussions 7, 203-245.

René, P., 2004. Variations glaciaires et changements climatiques dans les Pyrénées, Terre d'Océan no. 3, pp. 17-19.

Rolland, C., Florence-Schueller, J., 1998. Dendroclimatological synthesis on mountain pine (Pinus uncinata Mil. ex Mirb.) in the Pyrenees and the Alps. Ecologie 29 (1-2), 417-421.

Schar, C., Vidale, P.L., Luthi, D., Frei, C., Haberli, C., Liniger, M.A., Appenzeller, C., 2004. The role of increasing temperature variability in European summer heatwaves. Nature 427, 332-336.

Solmon, F., Giorgi, F., Liousse, C., 2006. Development of a regional anthropogenic aerosol model for climate studies: application and validation over a European/African domain. Tellus B 58, 51-72. 